\title{
700 years reconstruction of mercury and lead atmospheric deposition in the Pyrenees (NE Spain)
}

\author{
J.P. Corella ${ }^{a,}{ }^{*}$, B.L. Valero-Garcés ${ }^{b}$, F. Wang ${ }^{c}$, A. Martínez-Cortizas ${ }^{\text {d }}$, C.A. Cuevas ${ }^{\text {a }}$, \\ A. Saiz-Lopez ${ }^{\text {a }}$ \\ a Department of Atmospheric Chemistry and Climate, Institute of Physical Chemistry Rocasolano, CSIC, Serrano 119, 28006, Madrid, Spain \\ ${ }^{\mathrm{b}}$ Pyrenean Institute of Ecology, CSIC, Zaragoza, Spain, Avda Montañana 1005, 50059, Zaragoza, Spain \\ c Centre for Earth Observation Science, Department of Environment and Geography, University of Manitoba, Winnipeg, MB R3T 2N2, Canada \\ d Departamento de Edafología y Química Agrícola, Facultad de Biología, Universidad de Santiago de Compostela, Campus Sur E-15706, Santiago de \\ Compostela, Spain
}

\section{H I G H L I G H T S}

- Atmospheric $\mathrm{Hg}$ and $\mathrm{Pb}$ depositional history is reconstructed for the last $700 \mathrm{yrs}$.

- Atmospheric vs. run-off mercury input are detangled by microfacies analyses.

- Highest mercury accumulation occurred during World War II.

- Mercury fluxes are in agreement with those estimated by global inventories.

- Mining activities were the main contributors to $\mathrm{Hg}$ and $\mathrm{Pb}$ atmospheric fluxes.

\section{A R T I C L E I N F O}

\section{Article history:}

Received 31 October 2016

Received in revised form

6 February 2017

Accepted 8 February 2017

Available online 10 February 2017

\section{Keywords:}

Mercury

Lead

Pollution

Varves

Western Mediterranean

\begin{abstract}
A B S T R A C T
Geochemical analyses in varved lake sediment cores (Lake Montcortès, Pre-Pyrenees) allowed reconstruction of mercury $(\mathrm{Hg})$ and lead $(\mathrm{Pb})$ atmospheric deposition over the past seven centuries in the Pyrenees (NE Spain). Accumulation Rates (AR) from the Middle Ages to the Industrial Period ranged from 2500 to $26130 \mu \mathrm{g} \mathrm{m} \mathrm{m}^{2} \cdot \mathrm{y}^{-1}$ and $15-152 \mu \mathrm{g} \mathrm{m} \mathrm{m}^{2} \cdot \mathrm{y}^{-1}$ for $\mathrm{Pb}$ and $\mathrm{Hg}$ respectively. Significant metal pollution started ca CE 1550 during a period of increased exploitation of ore resources in Spain. Colder and humid conditions in the Pyrenees during the Little Ice Age may have also favoured $\mathrm{Hg}$ and $\mathrm{Pb}$ atmospheric deposition in the lake. Therefore, the interplay between increased rainfall (wet deposition) and mining activities in the Iberian Peninsula has driven $\mathrm{Hg}$ and $\mathrm{Pb}$ AR during the Pre-industrial Period. More recently, the use of leaded gasoline in Europe in the mid- $20^{\text {th }}$ century may explain the highest $\mathrm{Pb} \mathrm{AR}$ between CE 1953 and 1971. The highest Hg AR occurred in CE 1940 synchronous with the highest Hg production peak in Almadén mining district (southern Spain) and the Second World War. The record of $\mathrm{Hg}$ enrichment in Lake Montcortès shows a decrease during the last decades in Western Europe similar to other regional records and global emission models. This study highlights the exceptional quality of varved sequences to tease apart pollutants depositional mechanisms, identify historical periods of increased atmospheric pollution and provide a historical context for pollutant baseline values to make correct assessments of recent (atmospheric) pollution in lake ecosystems.
\end{abstract}

() 2017 Elsevier Ltd. All rights reserved.

\section{Introduction}

The contribution of atmospheric deposition on trace metal concentrations in soils and sediments is controlled by both the

\footnotetext{
* Corresponding author.

E-mail address: pcorella@iqfr.csic.es (J.P. Corella).
}

hydrological cycle and atmospheric patterns (Blais et al., 2015; Salomons and Förstner, 1984). Mercury $(\mathrm{Hg})$ and lead $(\mathrm{Pb})$ are major global pollutants subject to long-range transport, posing a threat for both human and environmental health at a global scale. During the last decade, both elements have been given priority attention by international programs aiming to reduce environmental and human exposure to them (AMAP/UNEP, 2013; Pacyna 
et al., 2009; Selin, 2009). Mercury and Pb are emitted to the atmosphere from both anthropogenic and natural sources. Nevertheless anthropogenic emissions have greatly exceeded natural release to the atmosphere over historical times (Amos et al., 2013; Engstrom et al., 2014; Martinez-Cortizas et al., 1999; Martínez Cortizas et al., 2012; Schwikowski et al., 2004), even at remote locations far from emission sources (Bindler et al., 2001; Fitzgerald et al., 1998; Lindeberg et al., 2006; Weiss et al., 1971). These anthropogenic emissions before the Industrial Period are mostly related to historical mining (Allan et al., 2013; Martinez-Cortizas et al., 1999, 2002). The Mediterranean has a long history of mining activities with the two world's largest $\mathrm{Hg}$ mines located in southern Spain (Almadén mining district) and Slovenia (Idrija mine). Almadén mines (Fig. 1), have alone contributed approximately one third of the globally mined $\mathrm{Hg}$, with an accumulated historic $\mathrm{Hg}$ emission estimate of 10000 tons (Hylander and Meili, 2003). Anthropogenic $\mathrm{Hg}$ release to the atmosphere due to mining activities in Almadén ca. 2500 years before present was first documented in peat cores from NW Spain (Martinez-Cortizas et al., 1999) and marine sediments in the Western Mediterranean (Portlligat Bay, Fig. 1) (Serrano et al., 2013). One decade after the closure of the mines in the early 2000s, total gaseous Hg concentrations in the air still exceeded the $\mathrm{Hg}$ World Health Organization (WHO) air quality standards (maximum recommended levels at $1000 \mathrm{ng} \mathrm{m}^{-3}$ ) for nearby urban areas (WHO, 2000; Tejero et al., 2015). In Idrija, more than 34000 tons of $\mathrm{Hg}$ were dissipated to the environment during five centuries of mining and significant mercury concentrations in the air are still present near the major sources of mercury vapour (Gosar et al., 1997). More locally, in the Pyrenees, the presence of ore deposits in the Bielsa-Parzán mining district (Fig. 1) may have been known since pre-Roman times (Calvo, 2008). In Lake Redó, for example, Camarero et al. (1998) detected a large increase in $\mathrm{Pb}$ concentrations in sediments dating to circa CE 500-700, that were attributed to, nonhistorically documented, mining activities in the area. However, $\mathrm{Pb}$ galena was not largely exploited until the $16^{\text {th }}$ century. Galena was subsequently smelted in local kilns. More than $15000 \mathrm{~kg}$ of lead were produced by the end of the 16th century (Nieto-Callen, 1996). The onset of large-scale $\mathrm{Pb}$ production started by the end of the $19^{\text {th }}$ century lasting until CE 1928, when the closure of the mines due to the decrease in $\mathrm{Pb}$ prices ended with the historical metal mining in this area (Calvo, 2008; Fanlo et al., 1998).

Natural archives (mostly peat and lacustrine sediments) have been widely used to reconstruct atmospheric depositional histories of pollutants - see Amos et al. (2015); Biester et al. (2007); Blais et al. (2015); Cloy et al. (2008); Engstrom et al. (2014) and references therein - since instrumental measurements of these atmospheric pollutants are scarce and barely span the last decades. Unfortunately there is an uneven distribution of atmospheric pollutants natural archives. Surprisingly, there is only a few reconstructions of $\mathrm{Hg}$ pollution during the last millennium in the Iberian Peninsula, where Almadén mines are located (MartinezCortizas et al., 1999, 2012; Serrano et al., 2011).

The quantification of atmospheric deposition using natural archives is not straightforward. In lake sediments it is often difficult to disentangle run-off inputs $v s$ atmospheric deposition of pollutants. Besides, metal remobilization in the sediment/water interphase caused by bioturbation and redox changes may affect some elements concentrations (Biester et al., 2007; Outridge and Wang, 2015). However, no apparent losses of total $\mathrm{Hg}$ seem to occur in lake sediments (Rydberg et al., 2008). On the other hand, ombrotrophic mires receive pollutants solely via atmospheric deposition (Martínez Cortizas et al., 2012; Shotyk et al., 1996). As a result, these records may suffer long periods of aerial exposure and inner diagenetic processes that tend to distort metal accumulation
(Biester et al., 2007; Enrico et al., 2016).

Annually laminated (i.e. varved) lake sediments located in small mountain catchments overcome these limitations since anoxic conditions in the lake's hypolimnion impede the alteration of surface sediments by bioturbation (Brauer, 2004). Their high chronological resolution, annual to seasonal, also provides a unique opportunity to quantify trace metals loads and to evaluate the long and short-term ecosystem's responses to the implementation of environmental policies. Unfortunately, studies on varved sediments are scarce and in some cases barely spanning a few decades (see for example Rydberg et al., 2008), mostly due to limnological changes caused by human-induced eutrophication processes (Hollander et al., 1992; Lotter et al., 1997). The varved Lake Montcortès is an annually-laminated record in the NE Iberian Peninsula with preservation of biogenic varves for the last millennia (Corella et al., 2011b, 2012). In this study we describe the trace metal record from this lake, which represents one of the few high-resolution reconstructions of $\mathrm{Hg}$ and $\mathrm{Pb}$ depositional history in southern Europe for the last 700 years. In addition, this study builds on previous investigations where endogenic and allochthonous sediments were well characterized (Corella et al., 2012, 2014, 2016). This detailed understanding of the lake's sedimentary microfacies and depositional processes has allowed us to discriminate the $\mathrm{Hg}$ and $\mathrm{Pb}$ inputs from the lake watershed (delivered to the lake via run-off) that may introduce noise to the atmospheric signal. We also provide an evaluation of the possible natural and anthropogenic sources of these metals, as well as the depositional processes operating at local and regional scales since the Middle Ages.

\section{Materials and methods}

\subsection{Study site}

Lake Montcortès is located in the southern Pre-Pyrenees $\left(42^{\circ} 19^{\prime}\right.$ $\mathrm{N}, 0^{\circ} 59^{\prime} \mathrm{E}, 1031 \mathrm{~m}$ a.s.l.), within the sub-Mediterranean bioclimatic domain, between the Mediterranean lowlands and the Middle Mountain belt (Rull et al., 2011). The lake was formed by karstic processes on Triassic evaporite-bearing formations (Corella et al., 2011b). The lake's watershed is relatively small $\left(1.39 \mathrm{~km}^{2}\right.$ surface area) and composed of carbonates and evaporites (Triassic) and conglomerates (Oligocene) (Fig. 1B). Meadows and pastures dominate in the watershed lowlands while deciduous and conifer forests cover the elevated areas (Corella et al., 2014). The morphology of the lake is almost circular, with a surface area of $0.14 \mathrm{~km}^{2}$, a maximum water depth of $\sim 30 \mathrm{~m}$ and steep margins. There is no permanent inlet (only an ephemeral stream located in the southern area of the lake) and the lake level is controlled by an outlet stream located in the northern shore and the groundwater inflow/outflow balance (Fig. 1B). A permanently anoxic monimolimnion is well developed below $18-20 \mathrm{~m}$ depth (Corella et al., 2012). Anoxic bottom conditions prevailed in the lake during the Late Holocene and enabled the preservation of biogenic varves punctuated by detrital layers related to run-off processes.

\subsection{Sediment cores and age model}

Two UWITEC gravity cores (MON12-3A-1G, $78 \mathrm{~cm}$ length, and MON12-2A-1G, $106 \mathrm{~cm}$ length) were retrieved at the deepest distal lake basin ( $30 \mathrm{~m}$ water depth) (Fig. 1C). The sediment cores were split lengthwise and high resolution images were obtained by the AVAATECH core scanner coupled camera. The sediment sequence was sampled in $26 \mathrm{~cm}$-long plastic holders for thin-section preparation following the methodology described by Brauer and Casanova (2001). Sedimentary facies characterization was performed by optical inspection of thin sections. A composite 


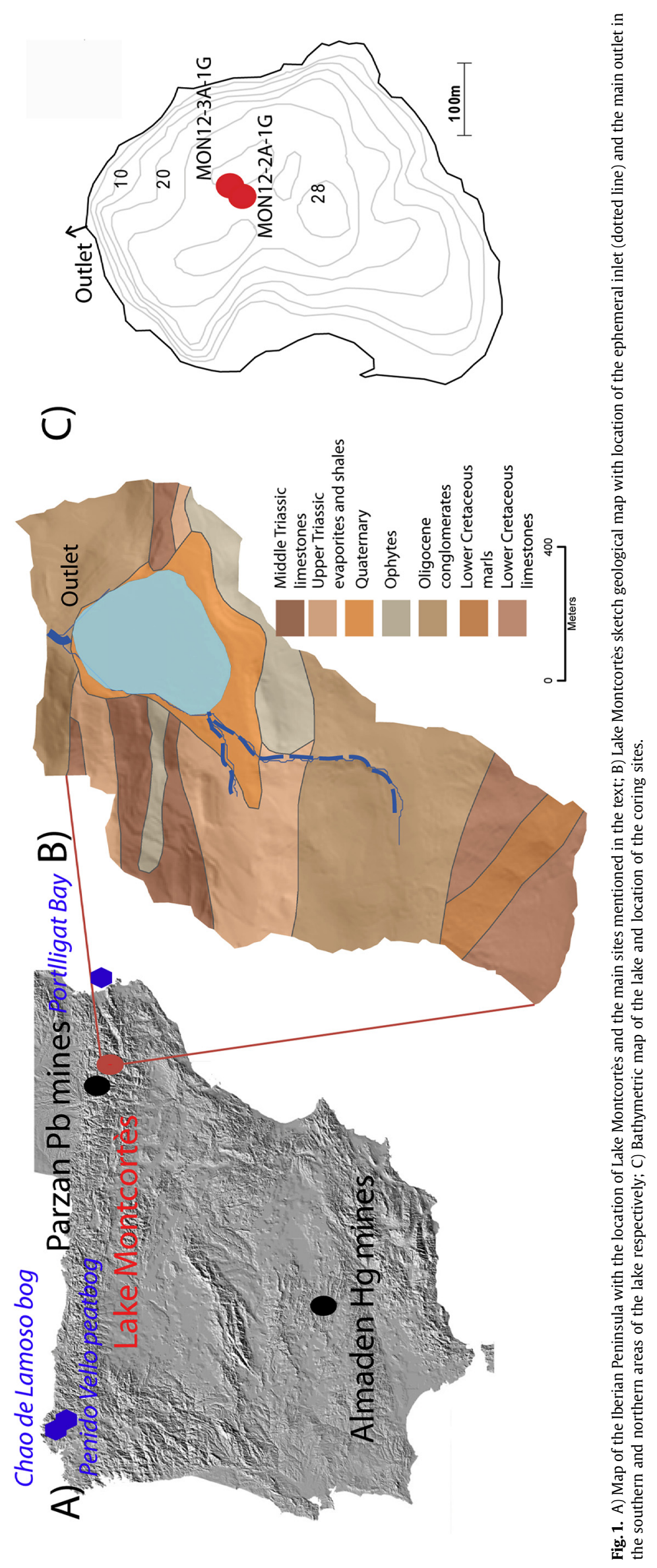


sedimentary sequence of $\sim 1 \mathrm{~m}$ in length was obtained by detailed facies correlation using marker layers - mostly detrital layers unequivocally identified in both sediment cores (Corella et al., 2014).

The age-depth model is based on two independent dating techniques: i) varve counting performed on calcite layers and ii) radiometric dating by ${ }^{210} \mathrm{~Pb}$ and ${ }^{14} \mathrm{C}$. Previous studies in Lake Montcortès documented a nonlinear varve counting error with a mean between 0 and 3\%. Less than $1 \%$ of varves were interpolated due to poor varve preservation in selected intervals (Corella et al., 2012 , 2014). Constant rate of supply (CRS) modeling of the ${ }^{210} \mathrm{~Pb}$ activities was applied to obtain the ${ }^{210} \mathrm{~Pb}$ chronology (Corella et al., 2014). The good agreement between both chronologies supports the robustness of Lake Montcortès age-depth model. The upper $1 \mathrm{~m}$ of sediment spans from CE 1386 to Present - see Corella et al. (2014) for further description of the age depth model -.

\subsection{Sediment sampling procedure}

Since the aim of this study is the reconstruction of atmospheric pollutants deposited in the lake sediments, sediment-laden deposits (i.e. detrital layers) from watershed runoff have to be considered. These detrital layers represent allochtonous material eroded from the lake catchment. Mass wasting events involving littoral material from the steep slopes of the lake are also recorded in the distal area of the lake sediments as mass movement turbidites -see Corella et al. (2014) for further details of sedimentary facies- which may contain metal concentrations that do not reflect direct atmospheric deposition. Both, detrital layers and mass wasting events are affected by lake's internal reworking processes and watershed hydrology, obscuring the atmospheric signal preserved in the lake sediments. Therefore, sediment samples from thinly laminated varved intervals were obtained after a detailed inspection of the sedimentary facies using a binocular scope $(\times 5$ magnification) in order to avoid $\mathrm{cm}$-thick detrital layers and turbidites that punctuate the sedimentary record.

\subsection{Geochemical analyses}

A suite of major and minor elements (e.g. $\mathrm{Zr}, \mathrm{Ti}, \mathrm{Zn}, \mathrm{Rb}, \mathrm{K}, \mathrm{S}, \mathrm{As}$, $\mathrm{Al}, \mathrm{Fe}, \mathrm{Br}, \mathrm{Cr}, \mathrm{Ca}, \mathrm{Sr}$ and $\mathrm{Si}$ ) were analyzed in the composite sedimentary sequence, at a vertical resolution of $0.2 \mathrm{~mm}$, using an X-ray fluorescence (XRF) AVAATECH core scanner (2000 A, 10-30 kV and 20-50 s measuring time). The results are given as counts per second (cps), providing high-resolution semi-quantitative information of the geochemical composition of the sediment down-core that was compared to microfacies.

A total of 87 discrete samples at a vertical resolution of $0.5-1 \mathrm{~cm}$ were analyzed quantitatively for $\mathrm{Hg}$ and $\mathrm{Pb}$. The samples were weighed before and after drying to estimate the sediment bulk density. The dried samples were acid digested on a microwave digestion system (MARS V of CEM). The digestant was then analyzed for $\mathrm{Pb}$ by inductively coupled plasma mass spectrometry (ICP-MS) on a PerkinElmer DRC II instrument, and for $\mathrm{Hg}$ by cold vapor atomic fluorescence spectroscopy (CVAFS) on a Tekran Model 2600 Mercury Analyzer. QA/QC for sediment core analysis was carried out using replicates, method blanks, field blanks, and a certified reference material (CRM, Buffalo River Sediment 8704 from NIST, USA). All measured samples showed less than 15\% deviation from CRM. Lead and $\mathrm{Hg}$ concentrations are expressed in $\mu \mathrm{g}$ $\mathrm{g}^{-1}$ of dry weight sediment. Mass accumulation rates were calculated as the product of their concentration in the sediment, the dry bulk density of the sediment, and sedimentation rates according to Givelet et al. (2003). Enrichment factors (EFs) of these two elements are commonly used to identify and quantify anthropogenic interferences in natural element cycles (Amos et al., 2015; Biester et al., 2007; Weiss et al., 1999). In this study, EFs have been calculated using the average element fluxes during the pre-medieval period -before CE 1550, following Amos et al. (2015), as baseline conditions which may differ from natural background values -:



\subsection{Statistical analysis}

Principal Component Analyses (PCA) was applied to reduce the large geochemical dataset into a smaller number of variables (i.e. principal components (PC). PCA was carried out including all the elements ( $\mathrm{Zr}$, Ti, Zn, Rb, K, S, As, $\mathrm{Al}, \mathrm{Fe}, \mathrm{Br}, \mathrm{Cr}, \mathrm{Ca}, \mathrm{Sr}, \mathrm{Pb}, \mathrm{Hg}$ and $\mathrm{Si}$ ). The XRF dataset was re-sampled every centimeter to obtain a homogeneous database. The PCA was performed with varimax rotation over the geochemical dataset using the SPSS 23.0 software. PCs were then be interpreted in terms of environmental and depositional processes (Giralt et al., 2008).

\section{Results and discussion}

\subsection{Lake sedimentary facies and geochemistry}

Annually-resolved biogenic varves characterize Lake Montcortès sedimentary sequence (Corella et al., 2011b). These varves are composed of calcite layers that precipitate due to enhanced bioproductivity during summer algal blooms, and organic detritus deposited throughout the year (Corella et al., 2012). Thin clastic laminae also occur within the carbonate and organic couplets and they record seasonal deposition by heavy storm events (Corella et al., 2016). Dry bulk densities of the biogenic varves show average values of $\sim 0.5 \mathrm{~g} \mathrm{~cm}^{-3}$ for the upper $10 \mathrm{~cm}$, and $0.7 \mathrm{~g} \mathrm{~cm}^{-3}$ for deeper sediments (Fig. 2). Turbidite layers punctuate the sedimentary record and are the result of sediment delivery to the lake during watershed run-off events. They display higher dry bulk densities $\left(\sim 1 \mathrm{~g} \mathrm{~cm}^{-3}\right)$ than biogenic varves. Three lithostratigraphic units have been defined according to the frequency of turbidites. The top (youngest) unit I (0-11.5 cm, 1902-2012 CE; $\left.\mathrm{AR}=0.13 \mathrm{~cm} \mathrm{yr}^{-1}\right)$ and bottom (oldest) unit III $(49-100 \mathrm{~cm}$, 1386-1844 CE; AR $\left.=0.11 \mathrm{~cm} \mathrm{yr}^{-1}\right)$ are mostly dominated by biogenic varves. Unit II $(11.5-49 \mathrm{~cm}, 1902-1844 \mathrm{CE})$ shows the highest turbidite frequency and thickness and the highest accumulation rates ( $\mathrm{AR}=0.64 \mathrm{~cm} \mathrm{yr}^{-1}$, Fig. 2). Turbidites were removed from the age-depth profile in order to calculate sediment fluxes.

The $\mu$-XRF downcore geochemical record shows a clear correspondence with the sedimentary facies. We have selected two elements ( $\mathrm{Ca}$ and $\mathrm{Zr}$ ) to illustrate the geochemical variability of the Montcortès record. The endogenic carbonate precipitation enrichment in units I and III is well defined by the calcium record, while the increase of turbidite frequencies and fining upwards texture is well-represented by the $\mathrm{Zr}$ record (Fig. 2). The total metal concentrations in Lake Montcortès sediment before the onset of the Industrial Period (lithostratigraphic unit III, 1386-1844 CE) range from 0.03 to $0.11 \mu \mathrm{g} \mathrm{g}^{-1}$ (mean values of $0.054 \mu \mathrm{g} \mathrm{g}^{-1}$; $\mathrm{sd}=0.01$ ) for $\mathrm{Hg}$ and $6.9-23 \mu \mathrm{g} \mathrm{g}^{-1}$ (mean values of $11.8 \mu \mathrm{g} \mathrm{g}^{-1}$; $\mathrm{sd}=2.9$ ) for $\mathrm{Pb}$. Since $1844 \mathrm{CE}$, metals concentrations in the sediment range between 0.05 and $0.2 \mu \mathrm{g} \mathrm{g}^{-1}$ (mean values of $0.11 \mu \mathrm{g} \mathrm{g}^{-1}$; sd $=0.03$ ) and $14.1-36.4 \mu \mathrm{g} \mathrm{g}^{-1}$ (mean values of $25.1 \mu \mathrm{g} \mathrm{g}^{-1}$; sd $=5.8$ ) for $\mathrm{Hg}$ and $\mathrm{Pb}$ respectively (Fig. 2). 


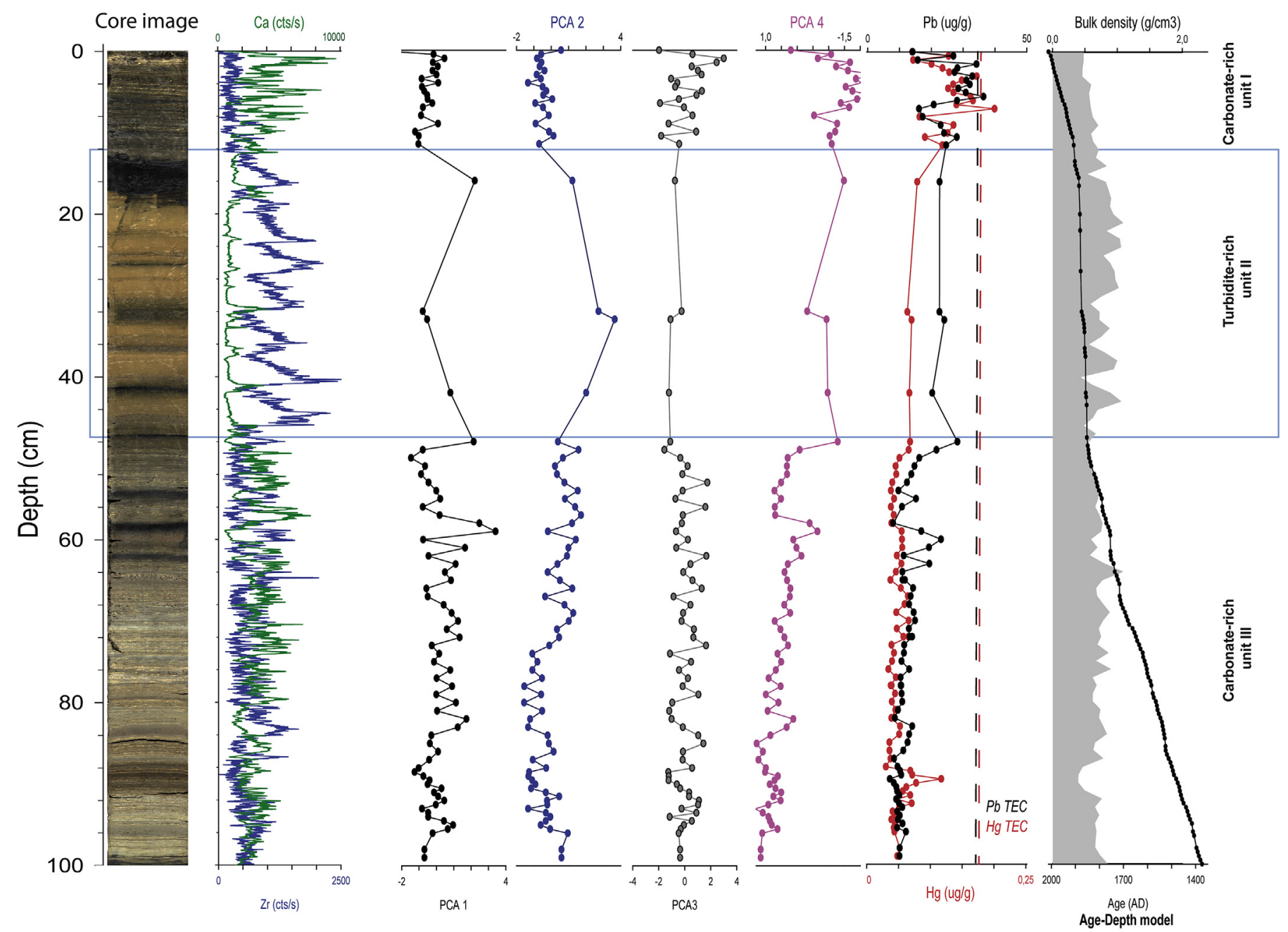

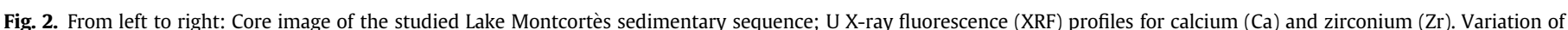

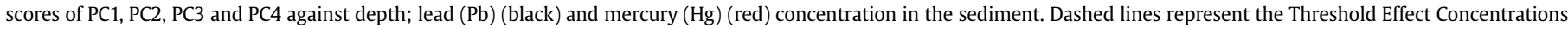

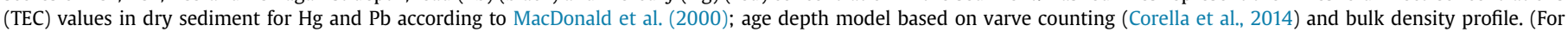
interpretation of the references to colour in this figure legend, the reader is referred to the web version of this article.)

\subsection{Environmental and depositional processes of trace metals in the lake}

PCA results show that multi-element relationships are related to the main environmental processes controlling sediment deposition in the lake. The four main eigenvectors account for $81.5 \%$ of the matrix variance (Table 1 ). The results of the PCA are presented in terms of factor loadings of each element in the extracted eigenvectors (PCs) highlighting the fractionation of the communalities (Fig. 3).

The first two components (PC1 and PC2, 48.7\% of accumulated variance) are related to lithogenic elements. Both PCs represent the delivery of allochtonous material to the lake via watershed run-off. PC1 is tied mainly to $\mathrm{Zr}, \mathrm{Ti}, \mathrm{Rb}$ and $\mathrm{K}$. On the other hand, PC2 is dominated by $\mathrm{S}$ and As with high positive loadings, and $\mathrm{Al}$ and $\mathrm{Fe}$ to a lesser extent. PC1 could represent material eroded from Oligocene conglomerates that outcrop in the northern area of the watershed (Fig. 1). PC2 may explain the input from Triassic evaporites and shales located in the southwestern area of the watershed. These facies are enriched in gypsum and arsenic (Heinrichs and Udluft, 1999). PC2 may also reflect redox variability in the hypolimnion since both elements ( $\mathrm{S}$ and As) are sensitive to redox-driven cycling in lacustrine systems (Hamilton-Taylor and Davison, 1995). The
Table 1

Results of the Principal Component Analyses using the scores (loading factors) of the extracted principal components obtained for the geochemical datasets.

\begin{tabular}{lllll}
\hline Element & PC1 & PC2 & PC3 & PC4 \\
\hline $\mathrm{Zr}$ & 0.87 & 0.12 & -0.29 & 0.16 \\
$\mathrm{Ti}$ & 0.84 & 0.32 & 0.27 & 0.20 \\
$\mathrm{Zn}$ & 0.84 & 0.26 & -0.33 & -0.07 \\
$\mathrm{Rb}$ & 0.83 & 0.27 & -0.34 & 0.16 \\
$\mathrm{~K}$ & 0.72 & 0.55 & -0.13 & 0.30 \\
$\mathrm{~S}$ & 0.37 & 0.75 & 0.02 & -0.03 \\
$\mathrm{As}$ & 0.11 & 0.74 & -0.23 & 0.05 \\
$\mathrm{Al}$ & 0.55 & 0.66 & -0.07 & 0.25 \\
$\mathrm{Fe}$ & 0.54 & 0.58 & -0.35 & 0.22 \\
$\mathrm{Br}$ & -0.15 & -0.58 & 0.22 & -0.04 \\
$\mathrm{Cr}$ & -0.10 & -0.12 & 0.93 & -0.13 \\
$\mathrm{Ca}$ & -0.23 & -0.17 & 0.91 & -0.05 \\
$\mathrm{Sr}$ & -0.14 & -0.27 & 0.71 & 0.41 \\
$\mathrm{Si}$ & 0.52 & 0.41 & -0.04 & 0.54 \\
$\mathrm{Hg}$ & -0.24 & -0.22 & -0.04 & -0.85 \\
$\mathrm{~Pb}$ & -0.06 & 0.05 & 0.03 & -0.93 \\
& & & & \\
$\mathrm{PCA}$ variance & 28.8 & 19.8 & 17.9 & 15.0 \\
$\mathrm{Accumulated}$ variance & 28.8 & 48.7 & 66.5 & 81.5 \\
\hline
\end{tabular}




\section{Communalities}
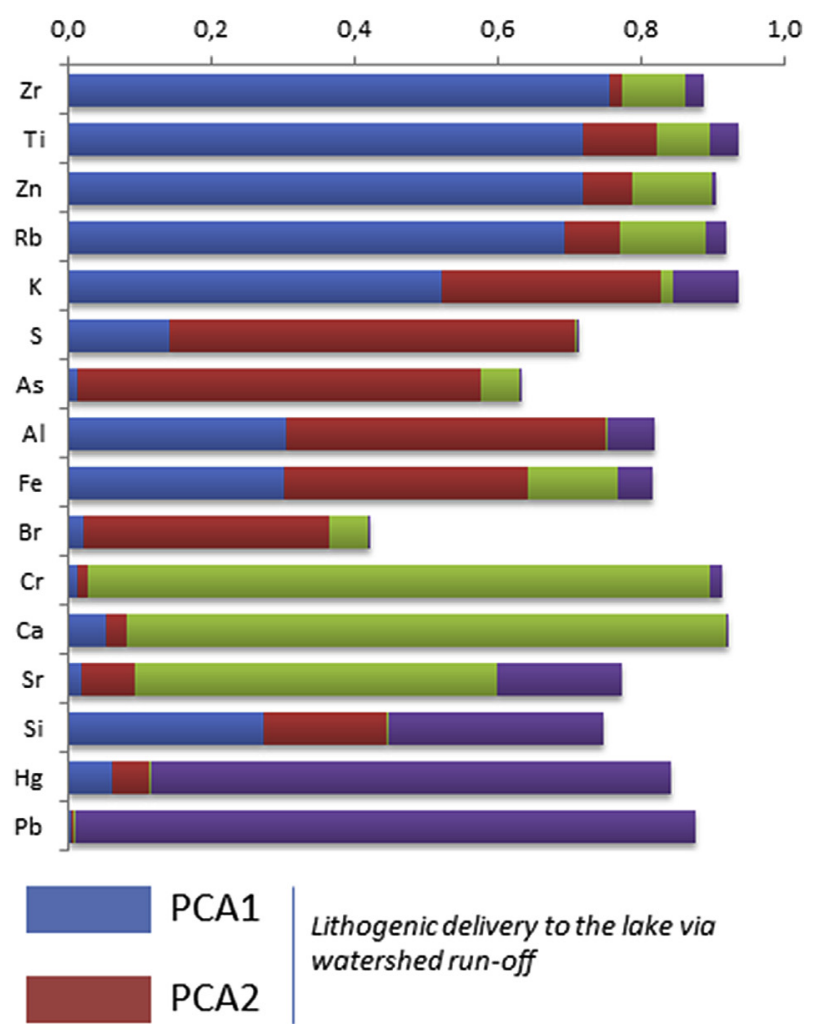

\section{PCA3 Lake's endogenic carbonate production}

\section{PCA4 Heavymetals atmospheric deposition}

Fig. 3. Communalities of the geochemical elements obtained from Principal Component Analyses (PCA).

correlation between Fe and S also suggest early diagenetic precipitation of pyrite under strong anoxic conditions (Corella et al., 2011b). PC1 and PC2 scores remained low and fairly constant during deposition of units I and III, but showed high scores in lithostratigraphic unit II (CE, 1844-1902). The period corresponding to Unit II (late 19th century) witnessed large regional floods (Barriendos and Llasat, 2003; Corella et al., 2014) and intense local land use (Rull et al., 2011) that may have led to an increased sediment delivery to the lake.

The third component (PC3, 17.9\% of the variance) is mainly characterized by positive loadings of $\mathrm{Ca}, \mathrm{Sr}$ and $\mathrm{Cr}$. The positive association of $\mathrm{Ca}$ and $\mathrm{Sr}$ suggests that $\mathrm{PC} 3$ reflects endogenic carbonate production in the lake - i.e. calcite layers deposition during spring-summer algal blooms (Corella et al., 2012) -. Thus, PC3 remained fairly constant down-core. Chromium mostly occurs in the Triassic shales from the watershed. Nevertheless, this element can be easily mobilized and re-precipitated with endogenic carbonates and fixed in the sediment under strong anoxic conditions in lake's hypolimnion (Nriagu et al., 1993).

The fourth component PC4 (15\% of the total variance) is characterized by large negative loadings of $\mathrm{Hg}(-0.85)$ and $\mathrm{Pb}(-0.93)$, suggesting atmospheric deposition as the main process controlling the sediment enrichment of these two major pollutants. The lack of correlation with lithogenic elements confirms that erosion and watershed runoff are minor contributors to $\mathrm{Hg}$ and $\mathrm{Pb}$ content and distribution in the sediment. PC4 scores show an increasing trend (i.e. $\mathrm{Hg}$ and $\mathrm{Pb}$ enrichment) since the onset of the Pre-Industrial period (Figs. 2 and 4). Strontium and Si show moderate positive loadings on PC4 ( 0.42 and 0.55 respectively). Both elements are largely linked to bioproductivity processes in the lake: $\mathrm{Si}$ is also related to biogenic Si associated to diatom blooms (Melles et al., 2012; Pellicer et al., 2016), while Sr can be associated to biogenic carbonates (Corella et al., 2011a) (bivalve shells and charophytes' stems; Anadón et al., 2002; Dodd and Crisp, 1982). The anticorrelation between $\mathrm{Hg}-\mathrm{Pb}$ and $\mathrm{Si}-\mathrm{Sr}$ may suggest a "biodilution effect" when enhanced algal blooms would result in lower biological concentration of pollutants (Pickhardt et al., 2002), which should be further investigated.

\subsection{Mercury and $\mathrm{Pb}$ atmospheric deposition since the 14th century}

The annually-resolved sediment record from Lake Montcortès allows us to reconstruct the $\mathrm{Hg}$ and $\mathrm{Pb}$ depositional evolution since CE 1386 with a sub-decadal resolution. As shown in Fig. 4, three main periods can be distinguished according to the changes in atmospheric metal deposition (PC4 scores): Pre-Colonial, Pre-Industrial and Industrial periods:

\subsubsection{Pre-Colonial period (CE 1386-1550)}

Atmospheric metal deposition shows the lowest values of the last 700 years during Medieval times. The average $\mathrm{Hg}$ concentration during this period is $0.054 \mu \mathrm{g} \mathrm{g}^{-1}$, representing the baseline conditions that may differ from natural background values since the anthropogenic contribution during the Medieval Period cannot be entirely ruled out. Lake Montcortès record shows two relative $\mathrm{Hg}$ AR peaks dated at CE $1454\left(48 \mu \mathrm{g} \cdot \mathrm{m}^{2} \cdot \mathrm{y}^{-1}\right)$ and CE 1488 (42 $\left.\mu \mathrm{g} \cdot \mathrm{m}^{2} \cdot \mathrm{y}^{-1}\right)$. These peaks occurred during a period of reduced precipitation (Corella et al., 2014, 2016, Fig. 4) and, therefore, an increase in $\mathrm{Hg}$ AR is unlikely. Furthermore, sedimentation rate is rather constant during this period ruling out intrinsic depositional processes that may explain these peaks. Therefore, the discrete nature of the $\mathrm{Hg}$ peaks points to two singular events. Interestingly, they correspond (based on temporal correlation) with two major volcanic eruptions - Kuwae (Vanuatu, Southern Pacific) and St Helens (EEUU) at 1452-1453 CE and 1480-1482 respectively (Yamaguchi, 1983; Gao et al., 2006). In particular Kuwae volcanoe delivered to the atmosphere some of the largest aerosol fluxes in the past 700 years (Gao et al., 2006). Enhanced $\mathrm{Hg}$ deposition during major eruptions has been reported in other remote locations (Daga et al., 2016; Ribeiro Guevara et al., 2010; Roos-Barraclough et al., 2002; Schuster et al., 2002). Volcanic eruptions are a major natural source of gaseous $\mathrm{Hg}$ emissions to the atmosphere (Nriagu and Becker, 2003), as large explosive eruption can release $>1000 \mathrm{Mg}$ of $\mathrm{Hg}$ per event (Pyle and Mather, 2003). If the Hg peaks recorded in Lake Montcortès are related to these volcanic events, it would suggest that $\mathrm{Hg}$ emissions from major volcanic eruptions can be transported inter-hemispherically and reach the western Mediterranean.

Lead accumulation rates in the Lake Montcortès sediment follow the same trend as that of the regional (paleo) precipitation reconstruction (Corella et al., 2014) (Fig. 4). The lowest $\mathrm{Pb}$ AR occurred between CE 1467 and 1498 (2500 $\left.\mu \mathrm{g} \cdot \mathrm{m}^{2} \cdot \mathrm{yr}^{-1}\right)$, agreeing very well with the largest aridity crises (i.e. reduced rainfall) of the last 700 years in NE Spain. Accumulation rates increased significantly again during a period of increasing precipitation between $\mathrm{CE}$ 1521 and 1557. This agreement between $\mathrm{Pb}$ accumulation and rainfall variability suggests that wet deposition controlled natural $\mathrm{Pb}$ atmospheric deposition in NE Iberian Peninsula during the Middle Ages. Increased rainfall may also increase the Pb fluxes to the lake from catchment soils via run-off, although this argument is less plausible since $\mathrm{Pb}$ does not correlate with run-off related 


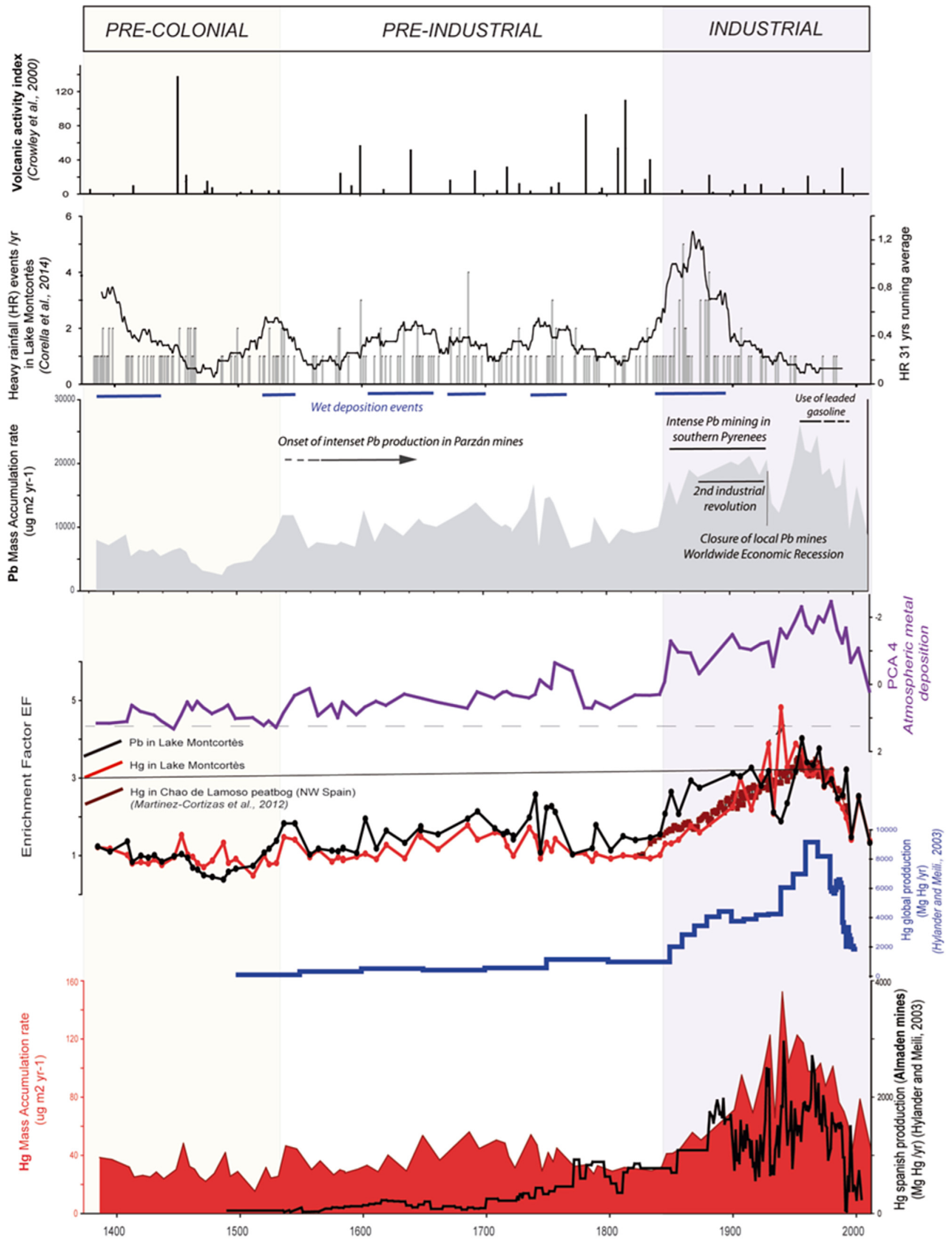

Age $A D$

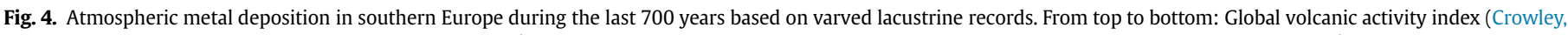

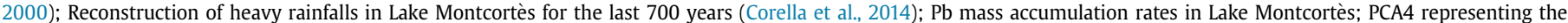

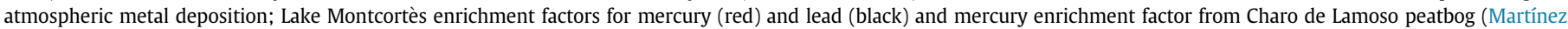

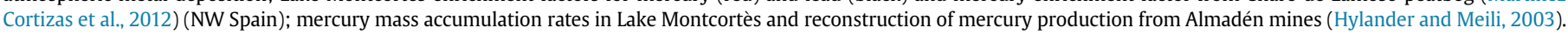
(For interpretation of the references to colour in this figure legend, the reader is referred to the web version of this article.) 
elements (Fig. 3) and sediment detrital layers were not considered in this study.

\subsubsection{Pre-industrial period (CE 1550-1840)}

The Montcortès record shows a progressive increase in atmospheric pollutants deposition since CE 1536 (negative PC4 scores, Figs. 2 and 4). A similar pattern has been documented in marine sediments (Posidonia oceanica mats) from Portlligat Bay (NE Spain, Fig. 1A) (Serrano et al., 2011) and the Chao de Lamoso peat record from NW Spain that showed a clear increase by that time (Martinez-Cortizas et al., 1999). Almadén Hg production and shipping for silver mining in the Spanish colonies greatly increased since CE 1555 and lasted for more than 250 years (Hylander and Meili, 2003). In addition, the increase in $\mathrm{Hg}$ mining in Idrija in the 16th century - estimated in 6380 tons, Hylander and Meili (2003) - most likely resulted in large amounts of $\mathrm{Hg}$ dissipated to the environment. Therefore, the increase in $\mathrm{Hg}$ release to the atmosphere related to $\mathrm{Hg}$ mining, storage and transport could explain the increase in Hg AR in Lake Montcortès sediments between CE 1536 and 1771 (mean Hg AR of $38.4 \mu \mathrm{g} . \mathrm{m}^{2} . \mathrm{yr}^{-1}$ ). This period also coincides with the coldest and most humid conditions of the last millennium in the Southern Pyrenees (Morellón et al., 2012) that would have favoured $\mathrm{Hg}$ deposition in Lake Montcortès since $\mathrm{Hg}$ accumulation is also controlled by temperature and humidity variations (Martinez-Cortizas et al., 1999). The decline of $\mathrm{Hg}$ AR in the lake since CE 1771 could also reflect the decrease in precipitation that experienced the area at the end of the $18^{\text {th }}$ century (Rull et al., 2011; Morellón et al., 2012; Corella et al., 2016). Therefore, we consider that the interplay between climate variability and anthropogenic mercury emissions from $\mathrm{Hg}$ mining in the Mediterranean area has driven $\mathrm{Hg}$ atmospheric deposition in Lake Montcortès during the Pre-Industrial Period.

Regional/continental increase in $\mathrm{Pb}$ mining and smelting in Europe may explain the $\mathrm{Pb}$ atmospheric contamination recorded in Lake Montcortès during the pre-industrial period. The increase in $\mathrm{Pb}$ AR between $\mathrm{CE} 1531$ and 1546 may respond to the increase in $\mathrm{Pb}$ mining in the nearby Royal Mines of Parzán (Nieto Callen, 1996). The development of new techniques for silver production required large amounts of $\mathrm{Pb}$ in Europe during the $16^{\text {th }}$ century. In addition, the widespread use of Pb-laden ammunition since the 15th century also led to higher $\mathrm{Pb}$ production in several European mining areas (Molenda et al., 1976). The CE 1531-1546 peak in Pb AR observed in Lake Montcortès also coincides with an abrupt increase in $\mathrm{Pb}$ deposition in lakes from northern Europe (Bränvall et al., 2001). Lead mining in Europe and the Pyrenees largely occurred during the Pre-industrial period, suggesting local and regional $\mathrm{Pb}$ mining and smelting activities as the most likely source of $\mathrm{Pb}$ atmospheric contamination in the lake during this period. These mining and roasting activities increased local $\mathrm{Pb}$ atmospheric emissions while increased rainfall contributed to increased $\mathrm{Pb}$ wet deposition into the lake (Fig. 4). Lead deposition reached the highest value ( 4000 $\left.\mu \mathrm{g} . \mathrm{m}^{2} . \mathrm{yr}^{-1}\right)$ of this period between 1735 and 1758 with a two-fold increase in the EF.

\subsubsection{Industrial period (CE 1840-present)}

The abrupt increase in industrial activities since the mid $19^{\text {th }}$ century led to a significant increase in the deposition of atmospheric pollutants, reaching maximum values between CE 1940s and 1960s (Fig. 4). After a several decade-long period (ca. CE $1780-1842)$ of low $\mathrm{Hg}$ deposition $\left(\sim 30 \mu \mathrm{g} \cdot \mathrm{m}^{2} \cdot \mathrm{yr}^{-1}\right)$, values progressively increased since the mid $19^{\text {th }}$ century (ca CE 1842) peaking during the mid $20^{\text {th }}$ century (mean AR $109 \mu \mathrm{g} \cdot \mathrm{m}^{2} \cdot \mathrm{yr}^{-1}$ ). Two major Hg deposition events occurred at CE 1930 and 1940, synchronous with two major $\mathrm{Hg}$ production maxima in Almadén mine (Hylander and Meili, 2003) (Fig. 4). Increasing demand of the weaponry industry for the production of $\mathrm{Hg}$ fulminates for explosive detonators and pharmaceutical needs may be responsible for the largest Hg deposition fluxes of more than 2830 tons in CE 1941 (Hernández et al., 1999). Both measurements and estimates performed at Almadén, suggest that roasting processes would have released up to 10 tons of $\mathrm{Hg}$ per year at a production up to 1500 tons of $\mathrm{Hg}$ per year (Ferrara et al., 1998). According to these estimates, 19 tons of $\mathrm{Hg}$ would have been released in CE 1941 in southern Spain solely in the Almadén mining district. Such large Hg emissions were likely responsible for the five-fold increase in $\mathrm{Hg}$ EF recorded in Lake Montcortès sediments. Higher $\mathrm{Hg}$ emissions during WWII not only occurred in Almadén as other mining district worldwide experienced a similar surge in production. Several sites in remote regions from South and North America have also shown high $\mathrm{Hg}$ accumulation rates around CE 1940 (Beal et al., 2015; Biester et al., 2002; Schuster et al., 2002). Coral skeletons from the South China Sea and North Atlantic myctophids, have also revealed the highest $\mathrm{Hg}$ concentrations in the marine realm during the WWII (Martins et al., 2006; Sun et al., 2016). This global increase in Hg deposition highlights the long-range atmospheric transport of gaseous $\mathrm{Hg}$, from anthropogenic emission sources to remote areas where atmospheric $\mathrm{Hg}$ can be oxidized to divalent $\mathrm{Hg}\left(\mathrm{Hg}^{\mathrm{II}}\right)$, and deposited onto terrestrial and marine ecosystems (Wang et al., 2014).

The $\mathrm{Hg}$ record of Lake Montcortès shows a decreasing trend since WWII, which does not match the Hg global production or the anthropogenic $\mathrm{Hg}$ emissions to the atmosphere related to widespread industrial uses of $\mathrm{Hg}$ (Fig. 4) (Horowitz et al., 2014; Hylander and Meili, 2003). Global reconstructions show the highest Hg AR between CE 1960 and 1980, while Montcortès record presents a progressive decrease after WWII, although accumulation rates remained high for the period CE 1945-1981 (mean $103 \mu \mathrm{g} . \mathrm{m}^{2} . \mathrm{yr}^{-1}$ ). This earlier late-industrial decline in $\mathrm{Hg}$ AR from Lake Montcortès is not observed in other $\mathrm{Hg}$ reconstructions from northern Europe or North America (Bindler et al., 2001; Engstrom and Swain, 1997; Lindeberg et al., 2007; Schuster et al., 2002), and thus appear to reflect more local factors (i.e. the reduction in Almadén $\mathrm{Hg}$ mining). In fact, a decreasing trend in mercury production in Almadén occurred since the 1960s (with up to 5200 flasks production per month) until the closure of the mines during the last decade (Tejero et al., 2015), which is in well agreement with the Lake Montcortès record. The reduction in $\mathrm{Hg}$ accumulation rates in Lake Montcortès has been estimated to be $40 \%$ since CE 1990 , in agreement with global emissions inventories that account for a reduction of $2.2 \%$ $\mathrm{yr}^{-1}$ in Western Europe (Zhang et al., 2016). This decrease in $\mathrm{Hg}$ depositional fluxes is most probably a consequence of the decline in $\mathrm{Hg}$ anthropogenic emissions in Europe related to; i) the closure of Almadén mines, ii) the phasing out of $\mathrm{Hg}$ for industrial uses (reduced use of $\mathrm{Hg}$ in products and their waste), iii) the marked reduction of $\mathrm{Hg}$ consumption in Western Europe chlor-alkali plants and iv) the emission decrease from coal-fired power plants (Horowitz et al., 2014; Zhang et al., 2016).

The large increase in $\mathrm{Pb}$ accumulation rates in Lake Montcortès between CE 1841 and 1970 is similar to other western Mediterranean and Pyrenean records and shows the massive rise in $\mathrm{Pb}$ pollution since the onset of the Industrial Revolution (Camarero et al., 1998; Elbaz-Poulichet et al., 2011; Martínez Cortizas et al., 2012; Rosman et al., 2000; Schwikowski et al., 2004; Shotyk et al., 1998; von Gunten et al., 1997). The first phase of atmospheric fallout of anthropogenic $\mathrm{Pb}$ before CE 1930 (mean $\mathrm{Pb}$ AR $2150 \mu \mathrm{g} . \mathrm{m}^{2} \cdot \mathrm{yr}^{-1}$ ) is the synergistic response of i) an increase in the frequency of rainfall events in the Central Pyrenees (Corella et al., 2014) enhancing $\mathrm{Pb}$ wet deposition; ii) increasing $\mathrm{Pb}$ regional emissions caused by higher production and advances in smelting techniques during the Second Industrial Revolution in Europe (CE 1870-1914) (Shotyk et al., 1998); and iii) renewed $\mathrm{Pb}$ mining in the 
Parzán area at the turn of the century (Fanlo et al., 1998). Lead isotopic studies conducted in the western Alps showed that regional and local mining, as well as smelting activities, were the dominant source of $\mathrm{Pb}$ pollution during this period (Rosman et al., 2000). The combined effect of local (closure of the Parzán mines in the early CE 1930s) and global (the worldwide economic recession during the 1930s) factors resulted in reduced $\mathrm{Pb}$ emissions and a decrease of Pb AR to almost Pre-industrial levels (Fig. 4). The onset of WWII caused a marked new increase in Pb AR that peaked between CE 1953 and 1971 (mean Pb AR $5920 \mu \mathrm{g} \cdot \mathrm{m}^{2} \cdot \mathrm{yr}^{-1}$ ), in agreement with other Pyrenean lake records (Camarero et al., 1998) and coastal lagoons from southwestern Mediterranean (Elbaz-Poulichet et al., 2011). These maxima $\mathrm{Pb}$ depositional fluxes are most likely due to the use of leaded gasoline, which greatly increased since 1950 and contributed to more than $60 \%$ of total emitted $\mathrm{Pb}$ (Schwikowski et al., 2004). The significant decline in $\mathrm{Pb}$ emissions in Western Europe since CE 1970 led to a progressive reduction in $\mathrm{Pb}$ deposition. Finally, the significant reduction of $\mathrm{Pb}$ deposition after CE 2003 to current levels is related to the total ban of leaded gasoline in Spain in CE 2001.

\subsection{Environmental implications}

The three to four-fold increase of $\mathrm{Hg}$ and $\mathrm{Pb} \mathrm{EF}$ in Lake Montcortès sediments during the $20^{\text {th }}$ century is in agreement with previous studies in ombrotrophic mires from NW Spain (Fig. 4) (Martínez Cortizas et al., 2012), but differs greatly with estimates from marine records in NE Spain (Portillag Bay, Fig. 1), where estimated $\mathrm{EF}$ for $\mathrm{Pb}$ and $\mathrm{Hg}$ were $>10$ (Serrano et al., 2013; Serrano et al., 2011). As the authors identified, the higher accumulation in the marine records is most likely due to the bioaccumulating capacity of Posidonia oceanica. This bioaccumulation may result in a magnification of trace metal concentrations as the plant acts as a pollutant sink. Lake Montcortès EF of $\mathrm{Hg}$ and $\mathrm{Pb}$ are consistent with global values of other peat records and lacustrine sequences - see review in Amos et al. (2015); Biester et al. (2007); Engstrom et al. (2014) - supporting that lake Montcortès varved sediments are a good archive of $\mathrm{Pb}$ and $\mathrm{Hg}$ atmospheric pollution in NE Spain.

Both $\mathrm{Hg}$ and $\mathrm{Pb}$ concentrations reached the Threshold Effect Concentration (TEC) in CE 1939 and 1956 respectively. TEC is a consensus-based sediment quality guideline that represents the pollutant concentrations above which adverse effects in freshwater ecosystems may occur (MacDonald et al., 2000). Although $\mathrm{Hg}$ and $\mathrm{Pb}$ levels have been significantly reduced in the last decades, this study suggests that atmospheric deposition of pollutants may reach significant levels that should be considered in lake's restoration strategies.

\section{Conclussions}

Geochemical analyses performed in sediment cores from varved Lake Montcortès, provide a high-resolution reconstruction of the $\mathrm{Hg}$ and $\mathrm{Pb}$ pollution history in Western Mediterranean since $\mathrm{CE}$ 1386. Low regional and global mining activity during medieval times was responsible for the low $\mathrm{Hg}$ values during this period. Volcanic eruptions may have been responsible for some $\mathrm{Hg}$ flux peaks recorded in sediments from Medieval times. During the Preindustrial period (CE 1550-1840) the interplay between i) $\mathrm{Hg}$ production from the two largest mercury mines (Almaden and Idrija) and ii) climate (colder and wetter conditions) may have controlled $\mathrm{Hg}$ deposition in the lake. Mercury accumulation rates experienced a significant increase during the Industrial period (after $1840 \mathrm{CE}$ ) with a five-fold increase during the WWII related to intense $\mathrm{Hg}$ mining in Almadén, coal burning and enhanced global mercury production. The decrease in $\mathrm{Hg}$ accumulation rates during the last decades is coherent with the observed trends in Hg emission inventories from Western Mediterranean, that account for a reduction of $\sim 2 \%$ per year since CE 1990 .

Local and regional mining and smelting practices controlled the Lake Montcortès $\mathrm{Pb}$ depositional fluxes during the Pre-industrial period. The use of leaded gasoline in Europe most likely triggered the highest $\mathrm{Pb}$ accumulation rates in the lake during the mid- $20^{\text {th }}$ century. The good correlation between periods of increased $\mathrm{Pb}$ deposition and higher rainfall favors wet deposition as an intensifier of $\mathrm{Pb}$ deposition.

The concentration of $\mathrm{Hg}$ and $\mathrm{Pb}$ in the sediments reached maximum values (exceeding TEC) in the mid $20^{\text {th }}$ century. Trace metal concentrations decreased since then as a consequence of reduced mining activities in the Iberian Peninsula and the implementation of environmental regulations during the last decades. This study helps to target limnological conditions and management strategies in aquatic ecosystems, and shows the need for highresolution (varved) records and multiproxy studies to make sound assessments of (atmospheric) pollution in lake ecosystems.

\section{Acknowledgments}

Juan Pablo Corella holds a post-doctoral contract funded by the Spanish Ministry of Economy and Competitiveness (contrato de formación postdoctoral JdC fellowship). FW acknowledges the financial support of the Natural Science and Engineering Research Council (NSERC) of Canada. BVG acknowledges the MEDLANT project funded by the MINECO (CGL2016-76215-R) of Spain.

\section{Appendix A. Supplementary data}

Supplementary data related to this article can be found at http:// dx.doi.org/10.1016/j.atmosenv.2017.02.018.

\section{References}

Allan, M., Le Roux, G., Sonke, J.E., Piotrowska, N., Streel, M., Fagel, N., 2013. Reconstructing historical atmospheric mercury deposition in Western Europe using: misten peat bog cores. Belg. Sci. Total Environ. 442, 290-301.

AMAP/UNEP, 2013. Technical Background Report for the Global Mercury Assessment, Arctic Monitoring and Assessment Programme, Oslo, Norway. UNEP Chemicals Branch, Geneva, Switzerland, 263 pp.

Amos, H.M., Jacob, D.J., Streets, D.G., Sunderland, E.M., 2013. Legacy impacts of alltime anthropogenic emissions on the global mercury cycle. Glob. Biogeochem. Cycles 27, 410-421.

Amos, H.M., Sonke, J.E., Obrist, D., Robins, N., Hagan, N., Horowitz, H.M., Mason, R.P., Witt, M., Hedgecock, I.M., Corbitt, E.S., 2015. Observational and modeling constraints on global anthropogenic enrichment of mercury. Environ. Sci. Technol. 49, 4036-4047.

Anadón, P., Utrilla, R., Vázquez, A., 2002. Mineralogy and Sr-Mg geochemistry of charophyte carbonates: a new tool for paleolimnological research. Earth Planet. Sci. Lett. 197, 205-214.

Barriendos, M., Llasat, M.C., 2003. The case of the 'maldá' anomaly in the western mediterranean basin (AD 1760-1800): an example of a strong climatic variability. Clim. Change 61, 191-216.

Beal, S.A., Osterberg, E.C., Zdanowicz, C.M., Fisher, D.A., 2015. Ice core perspective on mercury pollution during the past 600 years. Environ. Sci. Technol. 49, $7641-7647$

Biester, H., Bindler, R., Martinez-Cortizas, A., Engstrom, D.R., 2007. Modeling the past atmospheric deposition of mercury using natural archives. Environ. Sci. Technol. 41, 4851-4860.

Biester, H., Kilian, R., Franzen, C., Woda, C., Mangini, A., Schöler, H.F., 2002. Elevated mercury accumulation in a peat bog of the Magellanic Moorlands, Chile $\left(53^{\circ} \mathrm{S}\right)$ - an anthropogenic signal from the Southern Hemisphere. Earth Planet. Sci. Lett. 201, 609-620.

Bindler, R., Olofsson, C., Renberg, I., Frech, W., 2001. Temporal trends in mercury accumulation in lake sediments in Sweden. Water, Air Soil Pollut. Focus 1, 343-355.

Blais, J.M., Rosen, M.R., Smol, J.P., 2015. Environmental Contaminants. Using Natural Archives to Track Sources and Long-term Trends of Pollution. Springer, Netherlands.

Brauer, A., 2004. Annually Laminated Lake Sediments and Their Palaeoclimatic Relevance. Springer.

Bränvall, M.-L., Bindler, R., Emteryd, O., Renberg, I., 2001. Four thousand years of 
atmospheric lead pollution in northern Europe: a summary from Swedish lake sediments. J. Paleolimnol. 25, 421-435.

Brauer, A., Casanova, J., 2001. Chronology and depositional processes of the laminated sediment record from Lac d'Annecy, French Alps. J. Paleolimnol. 25, $163-177$.

Calvo, M., 2008. Minerales de Aragón. Prames, Zaragoza.

Camarero, L., Masqué, P., Devos, W., Ani-Ragolta, I., Catalan, J., Moor, H.C., Pla, S., Sanchez-Cabeza, J.A., 1998. Historical variations in lead fluxes in the Pyrenees (Northeast Spain) from a dated lake sediment core. Water, Air, Soil Pollut. 105, 439-449.

Cloy, J., Farmer, J., Graham, M., MacKenzie, A., Cook, G., 2008. Historical records of atmospheric $\mathrm{Pb}$ deposition in four Scottish ombrotrophic peat bogs: an isotopic comparison with other records from western Europe and Greenland. Glob. Biogeochem. Cycles 22.

Corella, J.P., Amrani, A., Sigró, J., Morellón, M., Rico, E., Valero-Garcés, B., 2011a. Recent evolution of Lake Arreo, northern Spain: influences of land use change and climate. J. Paleolimnol. 46, 469-485.

Corella, J.P., Benito, G., Rodriguez-Lloveras, X., Brauer, A., Valero-Garcés, B.L., 2014. Annually-resolved lake record of extreme hydro-meteorological events since AD 1347 in NE Iberian Peninsula. Quat. Sci. Rev. 93, 77-90.

Corella, J.P., Brauer, A., Mangili, C., Rull, V., Vegas-Vilarrúbia, T., Morellón, M., ValeroGarcés, B.L., 2012. The 1.5-ka varved record of Lake Montcortès (southern Pyrenees, NE Spain). Quat. Res. 78, 323-332.

Corella, J.P., Moreno, A., Morellón, M., Rull, V., Giralt, S., Rico, M.T., Pérez-Sanz, A., Valero-Garcés, B.L., 2011b. Climate and human impact on a meromictic lake during the last 6,000 years (Montcortès Lake, Central Pyrenees, Spain). J. Paleolimnol. 46, 351-367.

Corella, J.P., Valero-Garcés, B.L., Vicente-Serrano, S.M., Brauer, A., Benito, G., 2016. Three millennia of heavy rainfalls in Western Mediterranean: frequency, seasonality and atmospheric drivers. Sci. Rep. 6 http://dx.doi.org/10.1038/ srep38206, 38206.

Crowley, T.J., 2000. Causes of climate change over the past 1000 years. Science 289, $270-277$.

Daga, R., Ribeiro Guevara, S., Pavlin, M., Rizzo, A., Lojen, S., Vreča, P., Horvat, M., Arribére, M., 2016. Historical records of mercury in southern latitudes over 1600 years: lake futalaufquen, northern Patagonia. Sci. Total Environ. 553, 541-550.

Dodd, J.R., Crisp, E.L., 1982. Non-linear variation with salinity of $\mathrm{Sr} / \mathrm{Ca}$ and $\mathrm{Mg} / \mathrm{Ca}$ ratios in water and aragonitic bivalve shells and implications for paleosalinity studies. Palaeogeography, Palaeoclimatology, Palaeoecology 38, 45-56.

Elbaz-Poulichet, F., Dezileau, L., Freydier, R., Cossa, D., Sabatier, P., 2011. A 3500-year record of $\mathrm{Hg}$ and $\mathrm{Pb}$ contamination in a Mediterranean sedimentary archive (The Pierre Blanche Lagoon, France). Environ. Sci. Technol. 45, 8642-8647.

Engstrom, D.R., Fitzgerald, W.F., Cooke, C.A., Lamborg, C.H., Drevnick, P.E., Swain, E.B., Balogh, S.J., Balcom, P.H., 2014. Atmospheric Hg emissions from Preindustrial gold and silver extraction in the americas: a reevaluation from Lake-Sediment archives. Environ. Sci. Technol. 48, 6533-6543.

Engstrom, D.R., Swain, E.B., 1997. Recent declines in atmospheric mercury deposition in the upper midwest. Environ. Sci. Technol. 31, 960-967.

Enrico, M., Roux, G.l.L., Marusczak, N., Heimbürger, L.-E., Claustres, A., Fu, X., Sun, R., Sonke, J.E., 2016. Atmospheric mercury transfer to peat bogs dominated by gaseous elemental mercury dry deposition. Environ. Sci. Technol. 50, 2405-2412.

Fanlo, I., Touray, C.J., Subías, I., Fernández-Nieto, C., 1998. Geochemical patterns of a sheared fluorite vein, Parzan, spanish central Pyrenees. Miner. Deposita 33, $620-632$.

Ferrara, R., Maserti, B., Andersson, M., Edner, H., Ragnarson, P., Svanberg, S., Hernandez, A., 1998. Atmospheric mercury concentrations and fluxes in the Almadén district (Spain). Atmos. Environ. 32, 3897-3904.

Fitzgerald, W.F., Engstrom, D.R., Mason, R.P., Nater, E.A., 1998. The case for atmospheric mercury contamination in remote areas. Environ. Sci. Technol. 32, 1-7.

Gao, C., Robock, A., Self, S., Witter, J.B., Steffenson, J., Clausen, H.B., SiggaardAndersen, M.L., Johnsen, S., Mayewski, P.A., Ammann, C., 2006. The 1452 or 1453 AD Kuwae eruption signal derived from multiple ice core records: greatest volcanic sulfate event of the past 700 years. J. Geophys. Res. Atmos. 111.

Giralt, S., Moreno, A., Valero-Garcés, B., Sáez, A., Bao, R., Prego, R., Pueyo, J.J., González-Sampériz, P., Taberner, C., 2008. A statistical approach to disentangle environmental forcings in a lacustrine record: the Lago Chungará case (Chilean Altiplano). J. Paleolimnol. 40, 195-215.

Givelet, N., Roos-Barraclough, F., Shotyk, W., 2003. Predominant anthropogenic sources and rates of atmospheric mercury accumulation in southern Ontario recorded by peat cores from three bogs: comparison with natural "background" values (past 8000 years). J. Environ. Monit. 5, 935-949.

Gosar, M., Pirc, S., Ŝjn, R., Bidovec, M., Mashyanov, N.R., Sholupov, S.E., 1997. Distribution of mercury in the atmosphere over Idrija, Slovenia. Environ. Geochem. Health 19 (3), 101-112.

Hamilton-Taylor, J., Davison, W., 1995. Redox-driven cycling of trace elements in lakes. In: Physics and Chemistry of Lakes (Pp. 217-263). Springer, Berlin Heidelberg.

Heinrichs, G., Udluft, P., 1999. Natural arsenic in Triassic rocks: a source of drinkingwater contamination in Bavaria, Germany. Hydrogeology J. 7, 468-476.

Hernández, A., Jébrak, M., Higueras, P., Oyarzun, R., Morata, D., Munhá, J., 1999. The Almadén mercury mining district, Spain. Miner. Deposita 34, 539-548.

Hollander, D.J., McKenzie, J.A., Haven, H.L.t., 1992. A 200 year sedimentary record of progressive eutrophication in lake Greifen (Switzerland): implications for the origin of organic-carbon-rich sediments. Geology 20, 825-828.
Horowitz, H.M., Jacob, D.J., Amos, H.M., Streets, D.G., Sunderland, E.M., 2014. Historical mercury releases from commercial products: global environmental implications. Environ. Sci. Technol. 48, 10242-10250.

Hylander, L.D., Meili, M., 2003. 500 years of mercury production: global annual inventory by region until 2000 and associated emissions. Sci. Total Environ. 304, 13-27.

Lindeberg, C., Bindler, R., Bigler, C., Rosén, P., Renberg, I., 2007. Mercury pollution trends in subarctic lakes in the northern swedish mountains. AMBIO A J. Hum. Environ. 36, 401-405.

Lindeberg, C., Bindler, R., Renberg, I., Emteryd, O., Karlsson, E., Anderson, N.J., 2006. Natural fluctuations of mercury and lead in Greenland lake sediments. Environ. Sci. Technol. 40, 90-95.

Lotter, A., Sturm, M., Teranes, J., Wehrli, B., 1997. Varve formation since 1885 and high-resolution varve analyses in hypertrophic Baldeggersee (Switzerland). Aquat. Sci. 59, 304-325.

MacDonald, D.D., Ingersoll, C.G., Berger, T.A., 2000. Development and evaluation of consensus-based sediment quality guidelines for freshwater ecosystems. Arch. Environ. Contam. Toxicol. 39, 20-31.

Martinez-Cortizas, A., Garcia-Rodeja, E., Pombal, X.P., Munoz, J.C., ND, W., AK, C. 2002. Atmospheric $\mathrm{Pb}$ deposition in Spain during the last 4600 years recorded by two ombrotrophic peat bogs and implications for the use of peat as archive. Sci. Total Environ. 292, 33-44.

Martinez-Cortizas, A., Pontevedra-Pombal, X., García-Rodeja, E., Nóvoa, M.J.C. Shotyk, W., 1999. Mercury in a spanish peat bog: archive of climate change and atmospheric metal deposition. Science 284, 939-942.

Martínez Cortizas, A., Peiteado Varela, E., Bindler, R., Biester, H., Cheburkin, A., 2012 Reconstructing historical $\mathrm{Pb}$ and $\mathrm{Hg}$ pollution in NW Spain using multiple cores from the Chao de Lamoso bog (Xistral Mountains). Geochimica Cosmochimica Acta 82, 68-78.

Martins, I., Costa, V., Porteiro, F.M., Santos, R.S., 2006. Temporal and spatial changes in mercury concentrations in the North Atlantic as indicated by museum specimens of glacier lanternfish Benthosema glaciale (Pisces: myctophidae). Environ. Toxicol. 21, 528-532.

Melles, M., Brigham-Grette, J., Minyuk, P.S., Nowaczyk, N.R., Wennrich, V. DeConto, R.M., Anderson, P.M., Andreev, A.A., Coletti, A., Cook, T.L., 2012. 2.8 million years of Arctic climate change from Lake El'gygytgyn, NE Russia. Science 337, 315-320.

Molenda, D., 1976. Investments in ore mining in Poland from the 13th to the 17th centuries. J. Eur. Econ. Hist. 5 (1), 151.

Morellón, M., Pérez-Sanz, A., Corella, J.P., Büntgen, U., Catalán, J., GonzálezSampériz, P., González-Trueba, J.J., López-Sáez, J.A., Moreno, A., Pla-Rabes, S., Saz-Sánchez, M.A., Scussolini, P., Serrano, E., Steinhilber, F., Stefanova, V., VegasVilarrúbia, T., Valero-Garcés, B., 2012. A multi-proxy perspective on millennium-long climate variability in the Southern Pyrenees. Clim. Past 8, 683-700.

Nieto-Callen, J.J., 1996. El proceso sidero-metalúrgico altoaragones: Los valles de Bielsa y Gistain en la Edad Moderna (1565-1800). Llull 19, 471-507.

Nriagu, J., Beaubien, S., Blowes, D., 1993. Chemistry of chromium in lakes. Environ. Rev. 1, 104-120.

Nriagu, J., Becker, C., 2003. Volcanic emissions of mercury to the atmosphere: global and regional inventories. Sci. Total Environ. 304, 3-12.

Outridge, P.M., Wang, F., 2015. The Stability of Metal Profiles in Freshwater and Marine Sediments, Environmental Contaminants. Springer, pp. 35-60.

Pacyna, J.M., Pacyna, E.G., Aas, W., 2009. Changes of emissions and atmospheric deposition of mercury, lead, and cadmium. Atmos. Environ. 43, 117-127.

Pellicer, X.M., Corella, J.P., Gutiérrez, F., Roqué, C., Linares, R., Carbonel, D. Zarroca, M., Guerrero, J., Comas, X., 2016. Sedimentological and palaeohydrological characterization of Late Pleistocene and Holocene tufa mound palaeolakes using trenching methods in the Spanish Pyrenees. Sedimentology 63 (6), 1786-1819.

Pickhardt, P.C., Folt, C.L., Chen, C.Y., Klaue, B., Blum, J.D., 2002. Algal blooms reduce the uptake of toxic methylmercury in freshwater food webs. Proceedings of the National Academy of Sciences 99, 4419-4423.

Pyle, D.M., Mather, T.A., 2003. The importance of volcanic emissions for the global atmospheric mercury cycle. Atmos. Environ. 37, 5115-5124.

Ribeiro Guevara, S., Meili, M., Rizzo, A., Daga, R., Arribére, M., 2010. Sediment records of highly variable mercury inputs to mountain lakes in Patagonia during the past millennium. Atmos. Chem. Phys. 10, 3443-3453.

Roos-Barraclough, F., Martinez-Cortizas, A., Garcia-Rodeja, E., Shotyk, W., 2002. A 14500 year record of the accumulation of atmospheric mercury in peat: volcanic signals, anthropogenic influences and a correlation to bromine accumulation. Earth Planet. Sci. Lett. 202, 435-451.

Rosman, K.J.R., Ly, C., Van de Velde, K., Boutron, C.F., 2000. A two century record of lead isotopes in high altitude Alpine snow and ice. Earth Planet. Sci. Lett. 176, $413-424$

Rull, V., González-Sampériz, P., Corella, J., Morellón, M., Giralt, S., 2011. Vegetation changes in the southern Pyrenean flank during the last millennium in relation to climate and human activities: the Montcortès lacustrine record. J. Paleolimnol. 46, 387-404.

Rydberg, J., Gälman, V., Renberg, I., Bindler, R., Lambertsson, L., MartínezCortizas, A., 2008. Assessing the stability of mercury and methylmercury in a varved lake sediment deposit. Environ. Sci. Technol. 42, 4391-4396.

Salomons, W., Förstner, U., 1984. Metals in the Atmosphere, Metals in the Hydrocycle. Springer, pp. 99-137.

Schuster, P.F., Krabbenhoft, D.P., Naftz, D.L., Cecil, L.D., Olson, M.L., Dewild, J.F., 
Susong, D.D., Green, J.R., Abbott, M.L., 2002. Atmospheric mercury deposition during the last 270 Years: a glacial ice core record of natural and anthropogenic sources. Environ. Sci. Technol. 36, 2303-2310.

Schwikowski, M., Barbante, C., Doering, T., Gaeggeler, H.W., Boutron, C. Schotterer, U., Tobler, L., Van de Velde, K., Ferrari, C., Cozzi, G., Rosman, K. Cescon, P., 2004. Post-17th-Century changes of European lead emissions recorded in high-altitude alpine snow and ice. Environ. Sci. Technol. 38, 957-964.

Selin, N.E., 2009. Global biogeochemical cycling of mercury: a review. Annu. Rev. Environ. Resour. 34, 43

Serrano, O., Martínez-Cortizas, A., Mateo, M., Biester, H., Bindler, R., 2013. Millennia scale impact on the marine biogeochemical cycle of mercury from early mining on the Iberian Peninsula. Glob. Biogeochem. Cycles 27, 21-30.

Serrano, O., Mateo, M., Dueñas-Bohórquez, A., Renom, P., López-Sáez, J.A. Cortizas, A.M., 2011. The Posidonia oceanica marine sedimentary record: a Holocene archive of heavy metal pollution. Sci. Total Environ. 409, 4831-4840.

Shotyk, W., Cheburkin, A.K., Appleby, P.G., Fankhauser, A., Kramers, J.D., 1996. Two thousand years of atmospheric arsenic, antimony, and lead deposition recorded in an ombrotrophic peat bog profile, Jura Mountains, Switzerland. Earth Planet. Sci. Lett. 145, E1-E7.

Shotyk, W., Weiss, D., Appleby, P.G., Cheburkin, A.K., Frei, R., Gloor, M., Kramers, J.D. Reese, S., Van Der Knaap, W.O., 1998. History of atmospheric lead deposition since 12,370 14C yr BP from a peat bog, Jura mountains, Switzerland. Science 281, 1635-1640.

Sun, R., Hintelmann, H., Liu, Y., Li, X., Dimock, B., 2016. Two centuries of cora skeletons from the northern South China Sea record mercury emissions from modern chinese wars. Environ. Sci. Technol. 50, 5481-5488.

Tejero, J., Higueras, P.L., Garrido, I., Esbrí, J.M., Oyarzun, R., Español, S., 2015. An estimation of mercury concentrations in the local atmosphere of Almadén (Ciudad Real Province, South Central Spain) during the twentieth century. Environ. Sci. Pollut. Res. 22, 4833-4841.

von Gunten, H.R., Sturm, M., Moser, R.N., 1997. 200-Year record of metals in lake sediments and natural background concentrations. Environ. Sci. Technol. 31, 2193-2197.

Wang, F., Saiz-Lopez, A., Mahajan, A., Gómez Martín, J., Armstrong, D., Lemes, M. Hay, T., Prados-Roman, C., 2014. Enhanced production of oxidised mercury over the tropical Pacific Ocean: a key missing oxidation pathway. Atmos. Chem. Phys. $14,1323-1335$.

Weiss, D. Shotyk, W. Appleby, P.G., Kramers, J.D., Cheburkin, A.K., 1999. Atmospheric $\mathrm{Pb}$ deposition since the industrial revolution recorded by five Swiss peat profiles: enrichment factors, fluxes, isotopic composition, and sources. Environ. Sci. Technol. 33, 1340-1352.

Weiss, H.V., Koide, M., Goldberg, E.D., 1971. Mercury in a Greenland ice sheet: evidence of recent input by man. Science 174, 692-694.

WHO, 2000. European Series. Air Quality Guidelines for Europe, second ed., vol. 91. WHO Regional Publications. 273 pp.

Yamaguchi, D.K., 1983. New tree-ring dates for recent eruptions of Mount St. Helens. Quat. Res. 20 (2), 246-250.

Zhang, Y. Jacob, DJ., Horowitz, H.M., Chen, L, Amos, H.M., Krabbenhoft, D.P., Slemr, F., St. Louis, V.L., Sunderland, E.M., 2016. Observed decrease in atmospheric mercury explained by global decline in anthropogenic emissions. Proceedings of the National Academy of Sciences 113, 526-531. 